\title{
Research Paper Secondary nuclear targeting of mesoporous silica nano-particles for cancer-specific drug delivery based on charge inversion
}

\author{
Jianwen Zhao ${ }^{1,2, *}$, Fengfeng Zhao ${ }^{2, *}$, Xiyong Wang ${ }^{2}$, Xiaobo Fan' ${ }^{2}$, Guoqiu Wu ${ }^{1,2}$ \\ ${ }^{1}$ Center of Clinical Laboratory Medicine of Zhongda Hospital, Southeast University, Nanjing, 210009, China \\ ${ }^{2}$ Medical School, Southeast University, Nanjing, 210009, China \\ *These authors contributed equally to this work \\ Correspondence to: Xiaobo Fan, email: 101011951@seu.edu.cn \\ Guoqiu Wu, email: nationball@163.com
}

Keywords: peptide charge inversion, secondary nuclear targeting, mesoporous silica, cancer, delivery

Received: April 28, $2016 \quad$ Accepted: September 14, $2016 \quad$ Published: September 20, 2016

\section{ABSTRACT}

A novel multifunctional nano-drug delivery system based on reversal of peptide charge was successfully developed for anticancer drug delivery and imaging. Mesoporous silica nano-particles (MSN) 50 nm in diameter were chosen as the drug reservoirs, and their surfaces were modified with HIV-1 transactivator peptidefluorescein isothiocyanate (TAT-FITC) and YSA-BHQ1. The short TAT peptide labeled with FITC was used to facilitate intranuclear delivery, while the YSA peptide tagged with the BHQ1 quencher group was used to specifically bind to the tumor EphA2 membrane receptor. Citraconic anhydride (Cit) was used to invert the charge of the TAT peptide in neutral or weak alkaline conditions so that the positively charged YSA peptide could combine with the TAT peptide through electrostatic attraction. The FITC fluorescence was quenched by the spatial approach of BHQ1 after the two peptides bound to each other. However, the Cit-amino bond was unstable in the acidic atmosphere, so the positive charge of the TAT peptide was restored and the positively charged YSA moiety was repelled. The FITC fluorescence was recovered after the YSA-BHQ1 moiety was removed, and the TAT peptide led the nano-particles into the nucleolus. This nano-drug delivery system was stable at physiological $\mathrm{pH}$, rapidly released the drug in acidic buffer, and was easily taken up by MCF-7 cells. Compared with free doxorubicin hydrochloride at an equal concentration, this modified MSN loaded with doxorubicin molecules had an equivalent inhibitory effect on MCF-7 cells. This nano-drug delivery system is thus a promising method for simultaneous cancer diagnosis and therapy.

\section{INTRODUCTION}

Chemotherapy has greatly increased the survival rates of patients with cancer, but traditional chemotherapeutic drugs lack specificity and thus damage healthy cells/tissues, resulting in serious side-effects that immensely reduce the therapeutic effects [1-3]. Recently, nano-medicine carrier systems that actively and passively target cancerous cells have provided a promising alternative for the early diagnosis and treatment of cancer, due to their distinct pharmacokinetics and biological distribution $[4,5]$. The specific targeting and pharmacology of nano-particles could be improved by means of a decorating targeting segment on the surface, such as a vitamin, antibody, protein, aptamer, or peptide. This active targeting strategy could vastly improve the antineoplastic effects of anticancer drugs and increase the imaging sensitivity of tumor tissues by enhancing the signal-to-noise ratio [6-9].

It has been reported that the drug release from carrier systems occurs mainly in the cytoplasm, so the maximal anticancer effects cannot be achieved against targets inside the cell nucleus [10]. One solution to this has been to incorporate a nuclear localization signal (NLS) peptide into the carrier system, such as simian virus 40 T-antigen (SVT) or human immunodeficiency virus 1 transactivator protein (HIV TAT) [11-13]. The physicochemical properties, targeting potential and 
transposition mechanisms of these NLS peptides have been clearly demonstrated. NLS peptides first form a complex with importin $\alpha$ on the karyotheca. Then, importin $\beta$ is recruited to the complex, and the NLS peptides are conveniently transported into the nucleus [14-16]. However, NLS peptides can cause serious serum inhibition and are subject to plasma clearance because they are highly positively charged. The TAT peptide, for example, possesses a highly cationic motif of nine basic amino acids (KKKRRQRRR) [17-19]. Moreover, these peptides are usually nonspecific for tumor cells and thus poison normal cells as well. Therefore, single cellmembrane- or nuclear-receptor-targeting peptides are not the best choice for the decoration of nano-particles for drug delivery [17-20]. To solve all the abovementioned problems, our research group designed a drug delivery system based on peptide charge inversion, in order to achieve continuous multistage targeting and simultaneously perform fluorescent imaging and nuclear drug delivery.

Mesoporous silica nano-particles (MSN) are among the most promising drug-delivery vehicles, and have been used to fabricate controlled drug-release systems due to their remarkable properties, including easy synthesis, large pore volume, modifiable surface, uniform morphology, high biochemical and physicochemical stability, easy functionalization, good biocompatibility and very low cytotoxicity [21-26]. In addition, the vast numbers of original silanol groups $(\mathrm{Si}-\mathrm{OH})$ on MSN facilitate their post-functionalization $[21,24,26]$. Moreover, the US Food and Drug Administration has permitted the use of silicon nano-particles for biomedical applications [27]. Thus, we chose to use commercial MSN formed by a calcination process with a diameter of $\sim 50 \mathrm{~nm}$ as drug reservoirs, because the cellular nuclear pore complexes permit the active transport of particles $20-70 \mathrm{~nm}$ in size [14-16, 28, 29].

\section{RESULTS AND DISCUSSION}

\section{Characterization of MSN/COOH/TAT-FITC/Cit/ YSA-BHQ1/DOX}

The synthesis procedure of MSN/COOH/TATFITC/Cit/YSA-BHQ1/DOX is illustrated in Scheme 1. The functionalization of MSN was performed by a three-step superficial embellishment process. Firstly, the hydroxy groups on the MSN reacted with CPTS to form $\mathrm{MSN} / \mathrm{COOH}$, which made the surfaces of the nano-particles more negative. As illustrated in Figure 1, the zeta potential of $\mathrm{MSN} / \mathrm{COOH}$ was lower than that of crude MSN. The FT-IR spectrum of $\mathrm{MSN} / \mathrm{COOH}$ (Figure 2B) displayed peaks at $2900 \mathrm{~cm}^{-1}$ and 1470 $\mathrm{cm}^{-1}$, corresponding to the stretching vibration and bend vibration of $\mathrm{O}-\mathrm{H}$, respectively. The peak at $1680 \mathrm{~cm}^{-1}$ was due to the stretching vibration of $\mathrm{C}=\mathrm{O}[30,31]$.
Thermogravimetric analysis was used to estimate the grafting ratio of the surface modifications on the MSN. As demonstrated in Figure 3, the unmodified MSN (curve a) lost about $2 \mathrm{wt} \%$ before $120^{\circ} \mathrm{C}$, which was attributed to the elimination of adsorbed water on the surface [32]. As shown in Figure 3B, $9 \mathrm{wt} \%$ weight loss occurred at $800^{\circ} \mathrm{C}$. With consideration of the $2 \mathrm{wt} \%$ for adsorbed water on the MSN, it can be estimated that the content of CPTS on the MSN was about $7 \mathrm{wt} \%$.

Second, MSN/COOH was connected with the TAT-FITC peptides. The carboxyl group of MSN/COOH reacted with the amino of the TAT-FITC peptide via amidation reaction. As illustrated in Figure 1, the zeta potential of MSN/COOH/TAT-FITC was higher than that of $\mathrm{MSN} / \mathrm{COOH}$, because the TAT peptides bore positive charge. As shown in Figure 2C, peak absorptions at $1200 \mathrm{~cm}^{-1}$ and $1646 \mathrm{~cm}^{-1}$ were apparent in the FT-IR spectrum of MSN/COOH/TAT-FITC, corresponding to the stretching vibrations of $\mathrm{C}-\mathrm{N}$ and $\mathrm{C}=\mathrm{O}$, respectively. The peak at $660 \mathrm{~cm}^{-1}$ was attributed to the bend vibration of $\mathrm{N}-\mathrm{H}$. The stretching vibration of $\mathrm{N}-\mathrm{H}$ was around 3400 $\mathrm{cm}^{-1}$, which overlapped with that of $\mathrm{Si}-\mathrm{OH}[30,31]$. These results demonstrated that the TAT-FITC peptides were conjugated onto MSN/COOH. According to curve $\mathrm{c}$ in Figure 3, the amount of TAT-FITC that was grafted onto $\mathrm{MSN} / \mathrm{COOH}$ was about $14 \mathrm{wt} \%$. MSN/COOH/TAT-FITC could be visualized by the green color of FITC under the fluorescence microscope (Figure 4).

Finally, the YSA-BHQ1 peptides were combined with MSN/COOH/TAT-FITC through electrostatic interaction after the charge reversal of the TAT peptides. The sequence of the YSA peptide was derived from the EphA2-binding YSA peptide identified by phage display, which has been reported as an ephrin mimetic peptide that specifically binds to the EphA2 receptor [33]. EphA2 receptors are overexpressed in many types of carcinoma cells and tumor blood vessels, while they are not expressed in quiescent vasculature and are expressed at low levels in normal tissues and cells [33-35]. The amino-terminal portion of the YSA peptide appears to be the most important for EphA2 receptor binding and selectivity, while the carboxyl terminus is the region more amenable to modification without an effect on potency [36]. Thus, we tagged the carboxyl terminus of the YSA peptide with BHQ1 to avoid reducing the EphA2 binding activity [37]. The free terminal amine groups of YSA are cationic at a neutral $\mathrm{pH}$ [38]. As shown in Figure 1D, the zeta potential of MSN/COOH/TAT-FITC/Cit/YSA-BHQ1 was negatively charged $(-5 \mathrm{mv})$. The negative charge of the nano-particles decreased, because the YSA-BHQ1 peptides were positively charged. This feature has been shown to extend the in vivo circulation of nano-particles in the blood vessels by slowing their clearance by the reticuloendothelial system [39]. The grafting ratios of citraconic amide and YSA-BHQ1 on MSN were about $6 \mathrm{wt} \%$ and $14 \mathrm{wt} \%$, respectively (Figure 3D and 3E). After 
the loading of DOX, the amount of DOX on the MSN was estimated to be about $8 \mathrm{wt} \%$ (Figure $3 \mathrm{~F}$ ). Fluorescent imaging revealed that the fluorescence of $\mathrm{MSN} / \mathrm{COOH} /$ TAT-FITC/Cit/YSA-BHQ1 was quenched under neutral or alkaline conditions. In contrast, MSN/COOH/TAT-FITC/ Cit/YSA-BHQ1 fluoresced in an acidic environment, and the fluorescence intensity increased as the solution $\mathrm{pH}$ decreased (Figure 4). These results demonstrated that the YSA-BHQ1 peptides were repelled from MSN/ $\mathrm{COOH} / \mathrm{TAT}-\mathrm{FITC}$ under acidic conditions. After the peptide decoration, the nano-particles were obviously larger in size than the crude MSN (Figure 5). The TEM images revealed uniform size distributions for MSN and MSN/COOH/TAT-FITC/Cit/YSA-BHQ1, with average diameters of about $35 \mathrm{~nm}$ and $50 \mathrm{~nm}$, respectively.

The surface areas, pore sizes, and pore volumes of MSN and MSN/COOH/TAT-FITC/Cit/YSA-BHQ1/ DOX were measured by a nitrogen adsorption-desorption test. Figure 6 displays the nitrogen adsorption-desorption isotherms of the MSN and MSN/COOH/TAT-FITC/Cit/ YSA-BHQ1/DOX and the pore size distributive curves derived from the adsorption branches of the nitrogen isotherms by the Barrett-Joynere-Halenda method. These two samples displayed typical IV features for mesoporous silica according to the IUPAC classification, with welldefined steps at relative pressures of $0.2-0.4 P / P_{0}$. The MSN had a high specific surface area $\left(496 \mathrm{~m}^{2} / \mathrm{g}\right)$ and pore volume $(0.98 \mathrm{~mL} / \mathrm{g})$. However, the specific surface area and pore volume of MSN/COOH/TAT-FITC/Cit/YSABHQ1/DOX were reduced to $157 \mathrm{~m}^{2} / \mathrm{g}$ and $0.27 \mathrm{~mL} / \mathrm{g}$, respectively. This result should be largely attributed to the attachment of organic groups (i.e., TAT- FITC and YSA-BHQ1 peptides) and DOX molecules to the MSN surface or porous structures [40]. The average pore size of the MSN was $2.2 \mathrm{~nm}$, while the molecular diameter of DOX was estimated to be about $1.37 \mathrm{~nm}$ by Chemdraw software; thus, the MSN pores were large enough to be filled by the DOX molecules [41]. However, the average pore size of MSN/COOH/TAT-FITC/Cit/YSA-BHQ1/ DOX was reduced to $0.7 \mathrm{~nm}$, due to the DOX molecules filling the pores.

\section{DOX loading and release}

The loading efficiency and amount of the DOX molecules in the nano-particles were calculated by the following equations:

Loading efficiency $(\%, w / w)=((D O X$ in feed - free DOX )/DOX in feed) $\times 100$.

Loading amount $(\%, w / w)=((D O X$ in feed - free $\mathrm{DOX}) /$ nano-particles in feed) $\times 100$.

According to these equations, the loading efficiency and amount of the DOX molecules were $8.6 \pm 1.4 \%$ and $39.3 \pm 3.5 \%$, respectively, indicating that $\mathrm{MSN} / \mathrm{COOH} /$ TAT-FITC/Cit/YSA-BHQ1 could be used to effectively load DOX molecules.

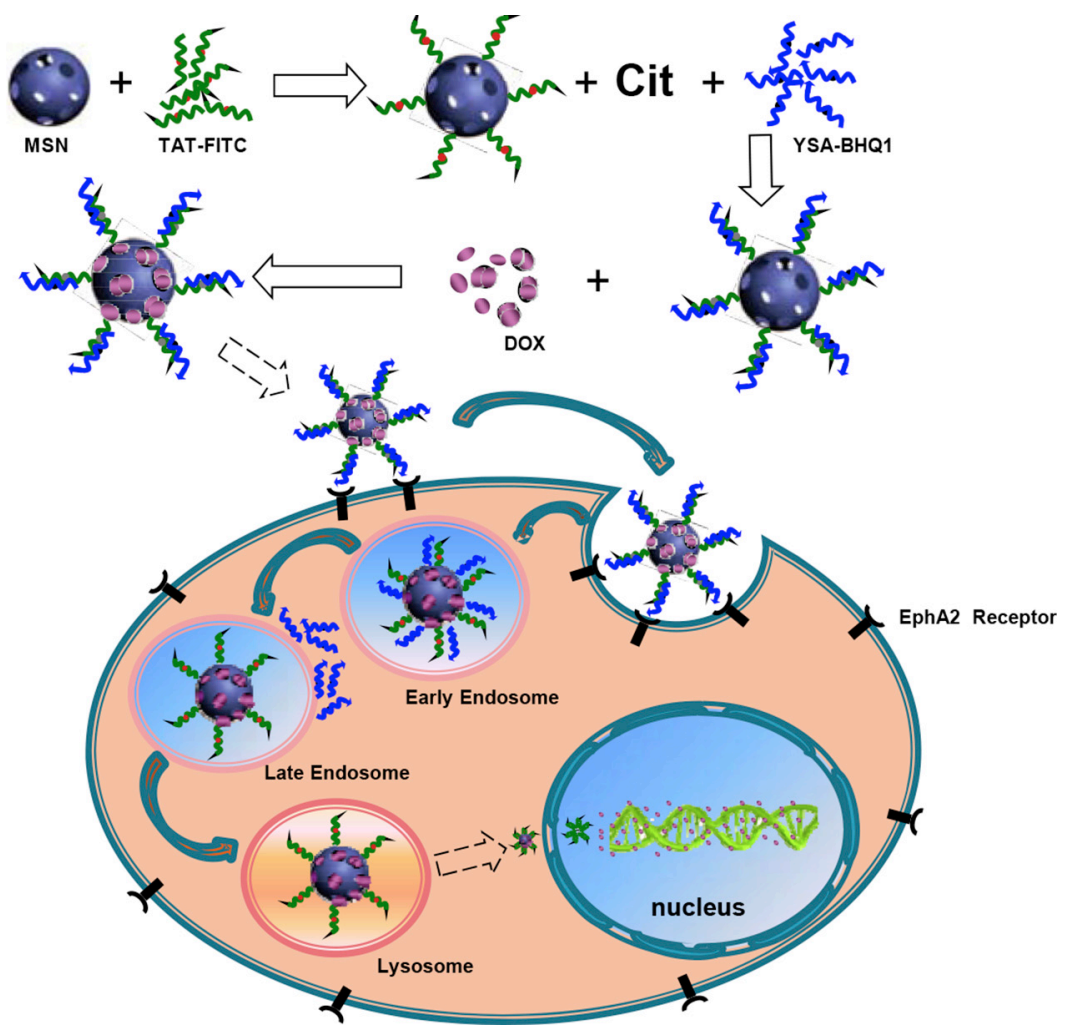

Scheme 1: Illustration of the synthesis and mechanism of action in MCF-7 cells of MSN/COOH/TAT-FITC/Cit/YSABHQ1/DOX. 
The release patterns of DOX molecules from MSN/ $\mathrm{COOH} / \mathrm{TAT}-\mathrm{FITC} / \mathrm{Cit} / \mathrm{YSA}-\mathrm{BHQ} 1$ were investigated under different $\mathrm{pH}$ conditions. As shown in Figure 7, the release amount of DOX molecules was considerably limited; only about $10 \%$ of the DOX molecules had been released after $10 \mathrm{~h}$ at $\mathrm{pH} 7.4$. This result indicated that the electrostatic interactions between DOX molecules and

A
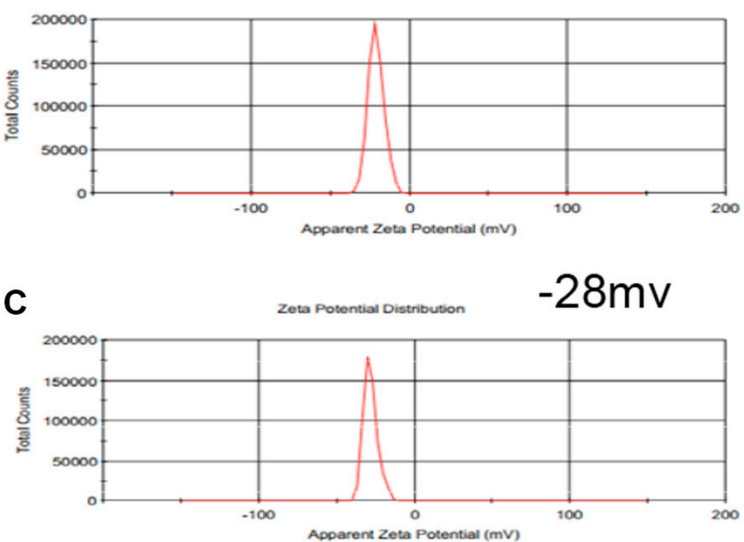

nano-particles were relatively stable under physiological $\mathrm{pH}$ conditions. However, an acidic atmosphere accelerated the release of DOX molecules; the release ratio reached $19 \%$ at $\mathrm{pH} 6.5$ and $34 \%$ at $\mathrm{pH} 5.0$ after $10 \mathrm{~h}$, indicating that the electrostatic interactions between DOX molecules and nano-particles were weakened by the protonation effect. This experiment clearly demonstrated that the

B
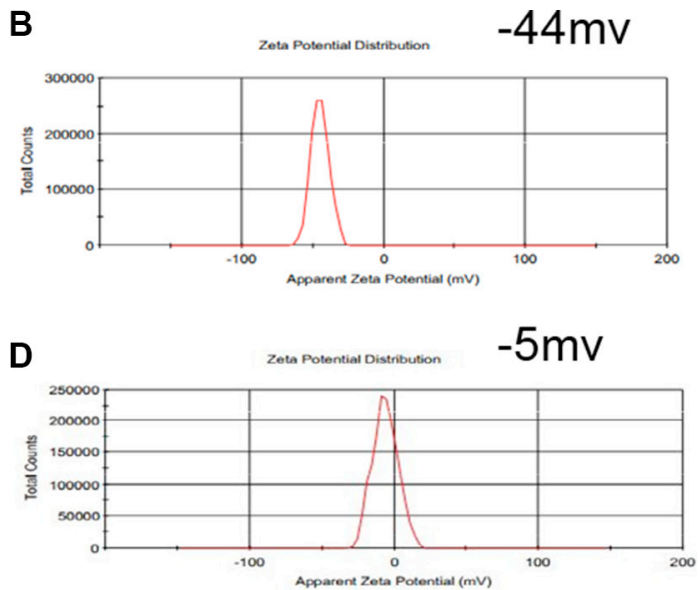

Figure 1: The zeta potentials of MSN (A), MSN/COOH (B), MSN/COOH/TAT-FITC (C), and MSN/COOH/TATFITC/Cit/YSA-BHQ1 (D).
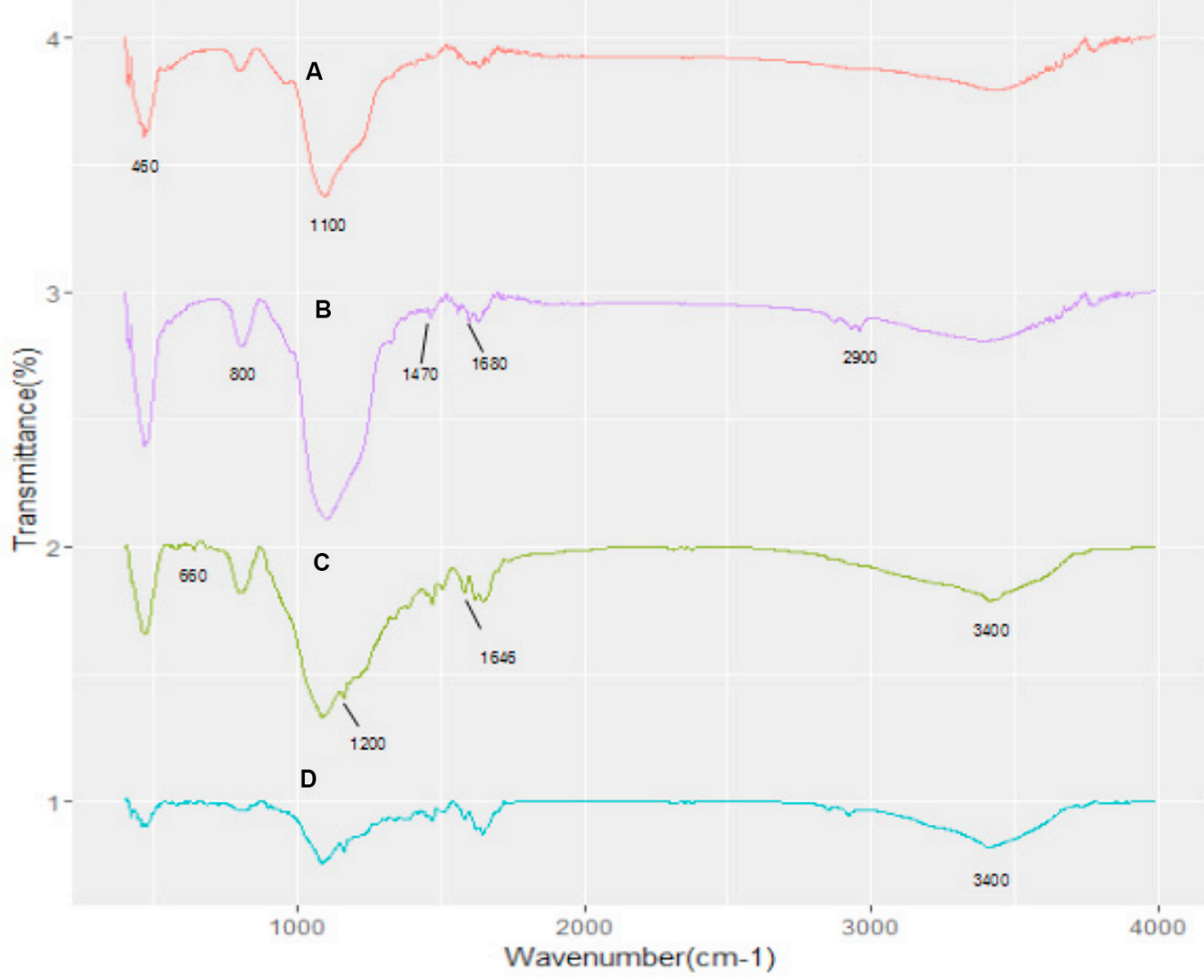

Figure 2: FT-IR spectra of MSN (A), MSN/COOH (B), MSN/COOH/TAT-FITC (C), and MSN/COOH/TAT-FITC/Cit/ YSA-BHQ1 (D). 
$\mathrm{pH}$ of the medium significantly influenced the quantity of DOX molecules released from the nano-particles. An explanation for this phenomenon may be that the acidic buffer weakened the electrostatic interactions between the DOX molecules and the nano-particles by neutralizing the negative charge, such that the DOX molecules were released from the charged complex. This $\mathrm{pH}$-dependant release behavior of drug carriers will be beneficial in promoting the release of DOX molecules at the tumor site, where the microenvironment is acidic. Thus, MSN/COOH/ TAT-FITC/Cit/YSA-BHQ1/DOX exhibited tremendous potential for use in cancer therapy.

\section{In vitro cytotoxicity studies}

MCF-7 and HEK293 cells were used to assess the in vitro cytotoxicity of the constructed nano-particles. As shown in Figure $8 \mathrm{~A}$ and $8 \mathrm{~B}, \mathrm{MSN}, \mathrm{MSN} / \mathrm{COOH} /$ TAT-FITC, and MSN/COOH/TAT-FITC/Cit/YSA-BHQ1 without DOX had very limited effects on the MCF-7 and HEK293 cells at different concentrations, indicating their good biocompatibility and the very low cytotoxicity of MSN/COOH/TAT-FITC/Cit/YSA-BHQ1 as a drug vehicle. However, MSN/COOH/DOX and MSN/COOH/ TAT-FITC/DOX demonstrated obvious toxicity against

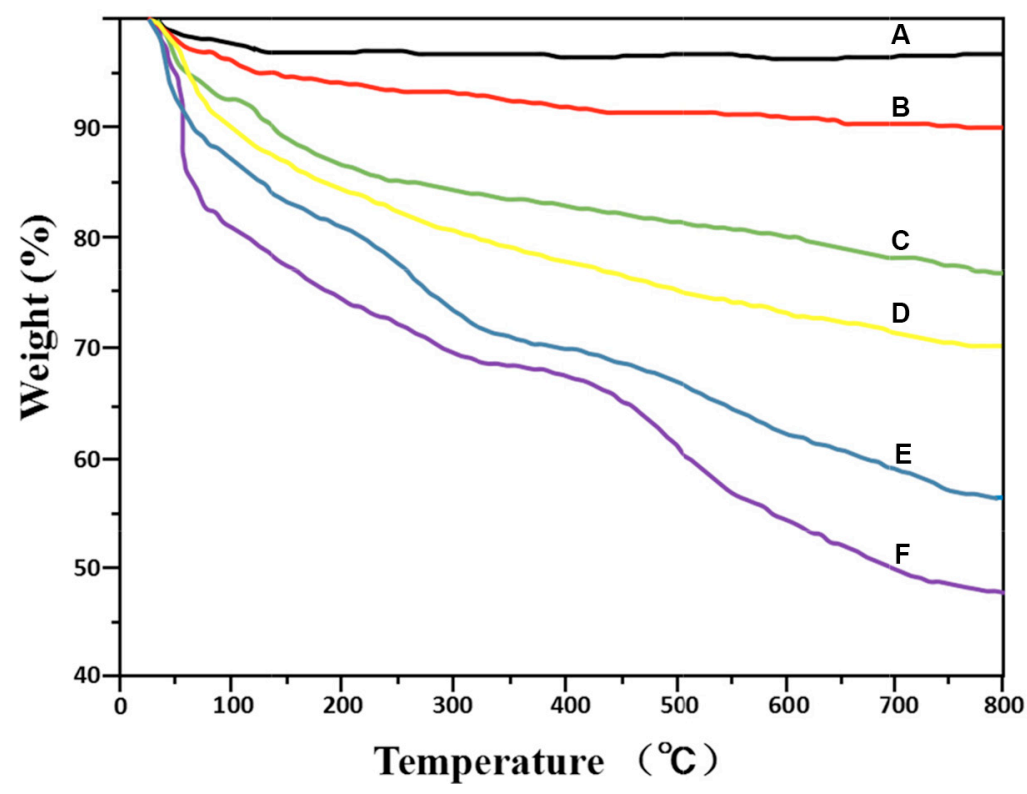

Figure 3: Thermogravimetric analysis curves of MSN (A), MSN/COOH (B), MSN/COOH/TAT-FITC (C), MSN/COOH/ TAT-FITC/Cit (D), MSN/COOH/TAT-FITC/Cit/YSA-BHQ1 (E), and MSN/COOH/TAT-FITC/Cit/YSA-BHQ1/DOX (F).
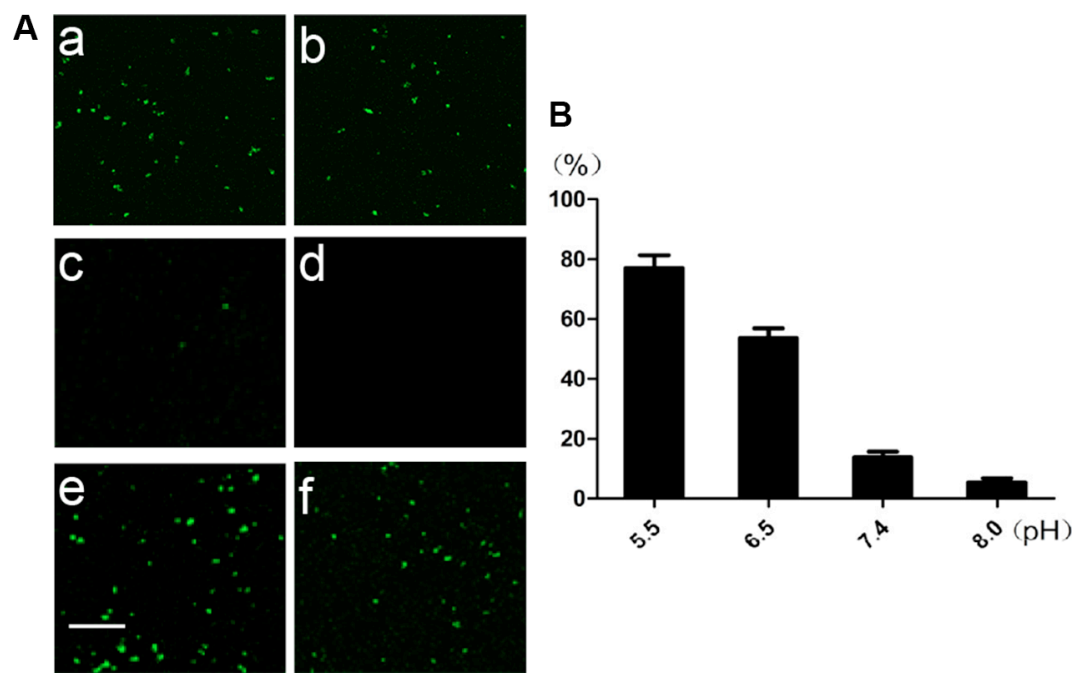

Figure 4: (A) Images of MSN/COOH/TAT-FITC/Cit/YSA-BHQ1 under the fluorescence microscope at pH 5.5 (a), 6.5 (b), 7.4 (c), and 8.0 (d), and images of MSN/COOH/TAT-FITC (e) and MSN/COOH/TAT-FITC/Cit (f) at pH 7.4. The scale bar is $100 \mu \mathrm{m}$. (B) The percentage of fluorescence intensity of MSN/COOH/TAT-FITC/Cit/YSA-BHQ1 at different pHs, compared with that of $\mathrm{MSN} / \mathrm{COOH} / \mathrm{TAT}-\mathrm{FITC}$ at $\mathrm{pH} 7.4$. 
MCF-7 and HEK293 cells. As a positive control, free DOX displayed the strongest inhibitory effect against MCF-7 and HEK293 cells among all the groups. This was because the molecular size of DOX is about $1.37 \mathrm{~nm}$ [41], so DOX can easily enter into cells and accumulate. The viability of
MCF-7 cells treated with the MSN/COOH/TAT-FITC/Cit/ YSA-BHQ1/DOX was equivalent to that of cells treated with free DOX, indicating that the YSA peptides were beneficial for the uptake of MSN/COOH/TAT-FITC/Cit/ YSA-BHQ1/DOX by MCF-7 cells via EphA2 receptor-
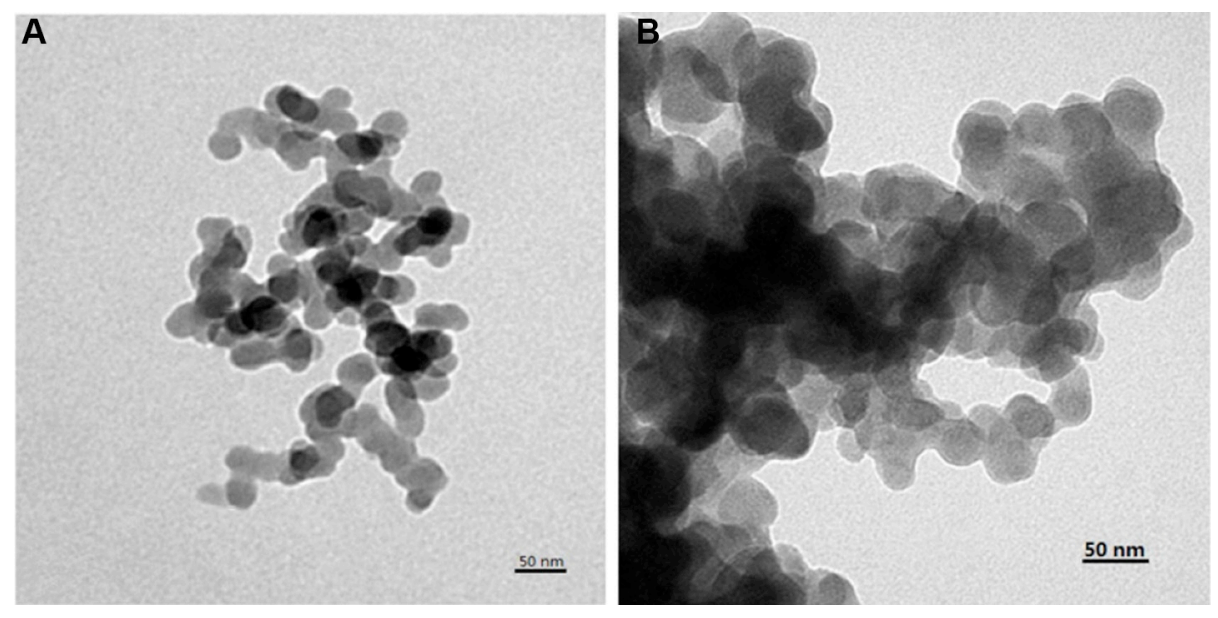

Figure 5: TEM images of MSN (A) and MSN/COOH/TAT-FITC/Cit/YSA-BHQ1 (B).
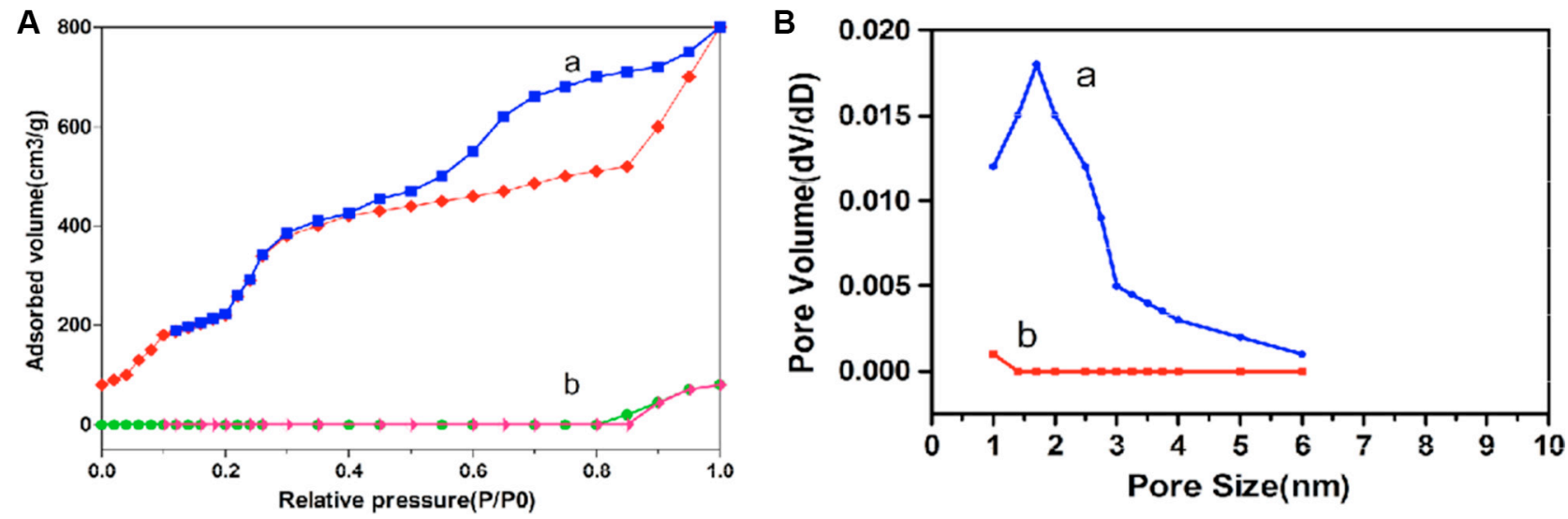

Figure 6: (A) Nitrogen adsorption-desorption isotherms of MSN (a) and MSN/COOH/TAT-FITC/Cit/YSA-BHQ1/DOX (b); (B) The pore size distributions of MSN (a) and MSN/COOH/TAT-FITC/Cit/YSA-BHQ1/DOX (b).

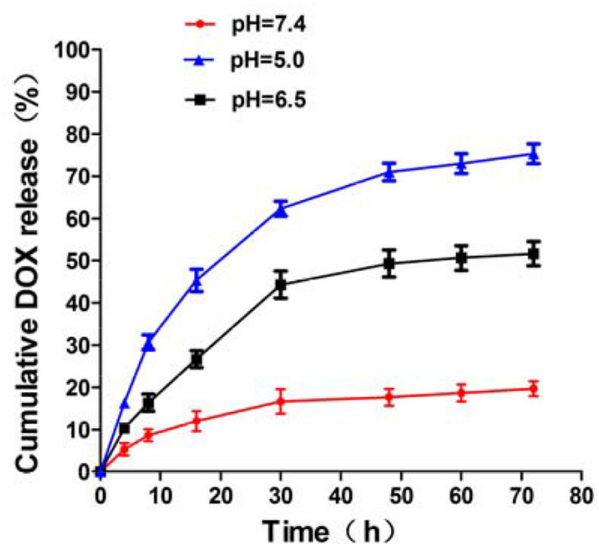

Figure 7: pH-dependent release of DOX molecules from MSN/COOH/TAT-FITC/Cit/YSA-BHQ1. 
mediated endocytosis, leading to enormous inhibition of MCF-7 cell growth. After treatment with MSN/COOH/ TAT-FITC/Cit/YSA-BHQ1/DOX, the HEK293 cells had higher viability than MCF-7 cells. The main reason for this was that far fewer EphA2 receptors are expressed by HEK293 cells than by MCF-7 cells, resulting in far lower extent of receptor-mediated endocytosis. Thus, it was difficult for MSN/COOH/TAT-FITC/Cit/YSABHQ1/DOX to be taken up by HEK293 cells, suggesting that MSN/COOH/TAT-FITC/Cit/YSA-BHQ1/DOX had limited toxicity to normal cells.

\section{Cell apoptosis study}

The apoptosis of MCF-7 and HEK293 cells after treatment with free DOX, MSN/COOH/DOX, MSN/ COOH/TAT-FITC/Cit/YSA-BHQ/DOX, or MSN/COOH/ TAT- FITC/Cit/YSA-BHQ1 was measured with a FACSCalibur Flow Cytometer. As shown in Figure 9, the free DOX molecules strongly promoted the apoptosis of MCF-7 and HEK293 cells, due to the easy entrance of the DOX molecules into the cells. Compared with free DOX, $\mathrm{MSN} / \mathrm{COOH} / \mathrm{DOX}$ induced apoptosis to a lesser extent in MCF-7 and HEK293 cells. However, MSN/COOH/TATFITC/Cit/YSA-BHQ1/DOX caused obvious apoptosis of MCF-7 cells, illustrating that the YSA peptides effectively targeted the MCF-7 cells and increased the cellular uptake of the nano-particles. MSN/COOH/TAT-FITC/Cit/YSABHQ1/DOX had a lesser effect on the apoptotic ratio of HEK293 cells, which should be attributed to very low
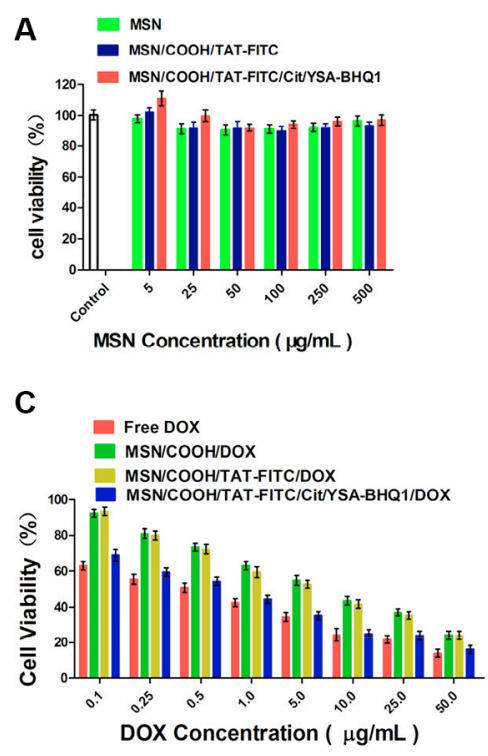

expression of EphA2 receptors on HEK293 cells. In addition, MSN/COOH/TAT-FITC/Cit/YSA-BHQ1 had little influence on the apoptosis of MCF-7 and HEK293 cells. This result again confirmed the safety of MSN/ COOH/TAT-FITC/Cit/YSA-BHQ1.

\section{Intracellular uptake of nano-particles}

CLSM was used to observe the uptake of MSN/ $\mathrm{COOH} / \mathrm{DOX}, \mathrm{MSN} / \mathrm{COOH} / \mathrm{TAT}-\mathrm{FITC} / \mathrm{DOX}, \mathrm{MSN} /$ $\mathrm{COOH} / \mathrm{TAT}-\mathrm{FITC} / \mathrm{Cit} / \mathrm{YSA}-\mathrm{BHQ} 1 / \mathrm{DOX}$ and free DOX molecules by MCF-7 and HEK293 cells (Figure 10). The red fluorescence represents the DOX molecules, while green fluorescence represents FITC and blue fluorescence represents DAPI. As shown in Figure 10, intense red fluorescence was observed in the MCF-7 cells treated with free DOX (Figure 10A), indicating that free DOX could quickly penetrate the cytomembrane and enter into the cells [42]. However, because free DOX can nonspecifically poison normal cells/tissues and cause serious side effects, its anticancer potential is limited. MCF-7 cells exposed to MSN/COOH/DOX (Figure 10B) or MSN/COOH/TAT-FITC/DOX (Figure 10C) exhibited a weak red fluorescence, indicating that a small quantity of DOX molecules had entered into the cells. Importantly, $\mathrm{MCF}-7$ cells displayed strong red and green fluorescence after treatment with MSN/COOH/TAT-FITC/Cit/YSABHQ1/DOX (Figure 10D), indicating the abundant accumulation of nano-particles inside the cells. This was because the YSA peptides on the nano-particles could

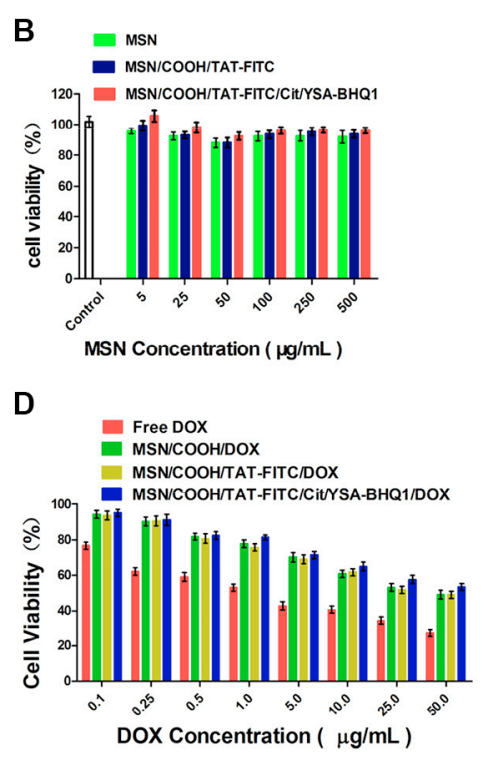

Figure 8: (A and B) Viability of MCF-7 and HEK293 cells after treatment with different nano-particles at $37^{\circ} \mathrm{C}$ for $24 \mathrm{~h}$ (MSN, MSN/COOH/TAT-FITC, or MSN/COOH/TAT-FITC/Cit/YSA-BHQ1 vs. control, $p>0.05$ ). (C) Viability of MCF-7 cells after treatment with DOX-loaded nano-particles or free DOX at $37^{\circ} \mathrm{C}$ for $24 \mathrm{~h}(\mathrm{MSN} / \mathrm{COOH} / \mathrm{DOX}$ or MSN/COOH/TAT-FITC/DOX vs. free DOX, $p<0.01$. MSN/COOH/TAT-FITC/Cit/YSA-BHQ1/DOX vs. free DOX, $p>0.05$ ). (D) Viability of HEK293 cells after treatment with DOX-loaded nano-particles or free DOX at $37^{\circ} \mathrm{C}$ for $24 \mathrm{~h}(\mathrm{MSN} / \mathrm{COOH} / \mathrm{DOX}, \mathrm{MSN} / \mathrm{COOH} / \mathrm{TAT}-\mathrm{FITC} / \mathrm{DOX}$, or MSN/COOH/TATFITC/Cit/YSA-BHQ1/DOX vs. free DOX, $p<0.01$ ). 
specifically bind to the EphA2 receptors overexpressed on the MCF-7 cell surface, such that nano-particle uptake was accelerated through specific receptor-mediated endocytosis. Consistent with this result, MCF-7 cells pre-treated with excess YSA peptides displayed weak red and green fluorescence after being exposed to MSN/ COOH/TAT-FITC/Cit/YSA-BHQ1/DOX (Figure 10E), because the large number of EphA2 receptors occupied by free YSA peptides prohibited the receptor-mediated binding of the YSA-functionalized MSN. Weak red and green fluorescence was observed after HEK293 cells were exposed to MSN/COOH/TAT-FITC/Cit/YSA- BHQ1/ DOX (Figure 10F), implying that only a small amount of MSN/COOH/TAT- FITC/Cit/YSA-BHQ1/DOX entered into the HEK293 cells. This was because EphA2 receptors are mainly expressed by tumor cells and barely present on normal cells/tissues [33, 43].

\section{MATERIALS AND METHODS}

MSN were purchased from Xinlei Powder Technology Limited Company (Bengbu, China). N-(3trimethoxysilylpropyl)-ethylenediamine triacetic acid trisodium salt (45\% in water) (CPTS) was purchased from Maror Chemistry Technology Limited Company (Shanghai, China). DOX (purity > 99\%) was obtained from Macklin Chemistry Technology Limited Company (Shanghai, China). The TAT-FITC (YGRKKKRRQRRRYK-FITC) and YSA-BHQ1 (YSAYPDSVMMSKRR- RRRBHQ1) peptides were purchased from Shanghai Ketai Biotechnology Limited Company (Shanghai, China). N-hydroxysulfosuccinimide sodium salt (sulfo-NHS), N-(3dimethylaminopropyl)-N-ethylcarbodiimide hydrochloride (EDC), 2-(N- Morpholino) ethanesulfonic acid (MES), and
Cit were obtained from Aladdin Co. (Shanghai, China). DMEM, fetal bovine serum (FBS) and trypsin were acquired from Gibco. DAPI was purchased from Beyotime Institute of Biotechnology (Shanghai, China). Cell Counting Kit-8 (CCK-8) was purchased from Dojindo (Japan). The Annexin V-FITC \& PI Apoptosis Kit was obtained from Ubio Biotechnology Pvt Ltd (Beijing, China). All other reagents were of analytical grade.

\section{Synthesis of carboxyl-functionalized MSN (MSN/COOH)}

First, MSN were functionalized through the addition of carboxyl groups onto their surfaces by CPTS [44]. Briefly, $10 \mathrm{mg}$ MSN was dissolved in $10 \mathrm{~mL}$ absolute ethyl alcohol, and $100 \mu \mathrm{L}$ CPTS was added dropwise under stirring at $80^{\circ} \mathrm{C}$ in airtight conditions, followed by incubation for $24 \mathrm{~h}$ at room temperature. The samples were collected by centrifugation at $9000 \mathrm{rpm}$ for $5 \mathrm{~min}$, and then washed with ethyl alcohol to remove the excess CPTS. Finally, the precipitates were freeze-dried for further use.

\section{Combination of MSN/COOH with the TAT- FITC peptides (MSN/COOH/TAT- FITC)}

Samples of MSN/COOH (10 mg) were dissolved in $10 \mathrm{~mL}$ isotonic MES saline buffer (0.1 M, pH 5.5), and $10 \mathrm{mg}$ each of EDC and sulfo-NHS were added into the solution under stirring $(300 \mathrm{rpm})$ at room temperature. After $2 \mathrm{~h}$, the mixture was centrifuged at $9000 \mathrm{rpm}$ for 5 min and washed with ultrapure water to remove the excess EDC, sulfo-NHS and other by-products. The precipitates were collected and resuspended in $10 \mathrm{~mL}$ isotonic MES
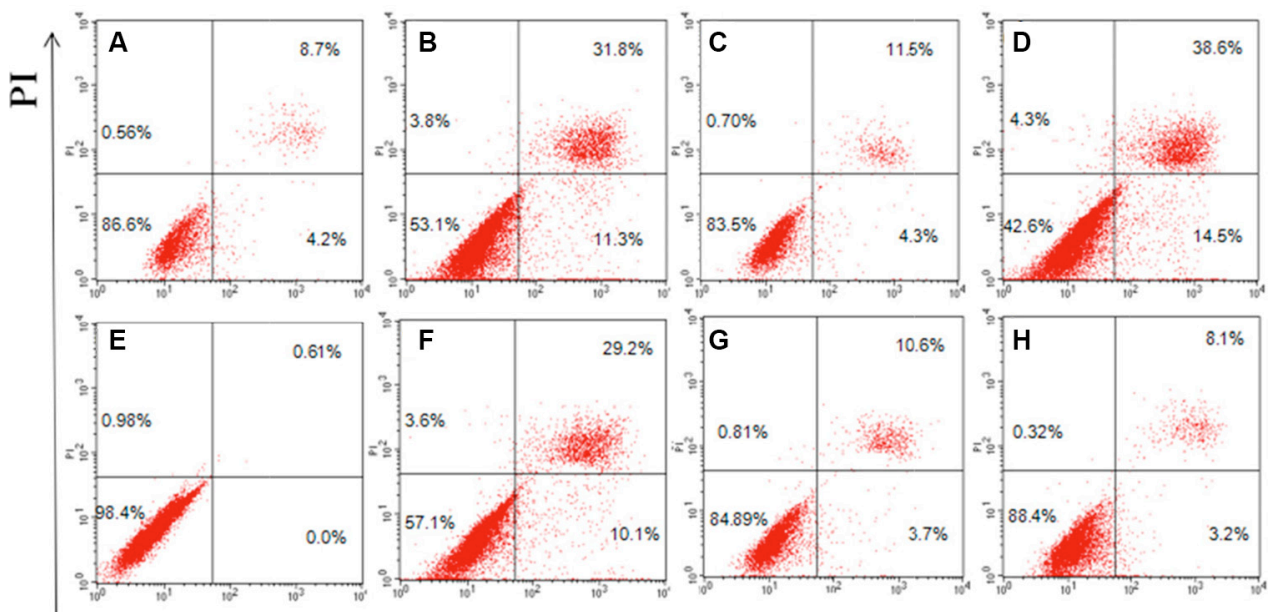

Annexin V-FITC

Figure 9: Flow cytometry analysis for apoptosis of MCF-7 (A-D) and HEK293 cells (E-H) induced by MSN/COOH/ TAT-FITC/Cit/YSA-BHQ1, free DOX, MSN/COOH/DOX, or MSN/COOH/TAT-FITC/Cit/YSA-BHQ1/DOX for $24 \mathrm{~h}$, respectively. (Lower-right quadrant: early apoptotic cells, i.e., Annexin V-FITC-positive/PI-negative cells; upper-right quadrant: necrotic or late-apoptotic cells, i.e., Annexin V-FITC-positive/PI-positive cells). 
saline buffer (0.1 M, pH 8), and $1 \mathrm{mg}$ TAT-FITC peptide was added under stirring $(300 \mathrm{rpm})$ at room temperature for $24 \mathrm{~h}$ in the dark. The samples were retrieved by centrifugation (9000 rpm, $5 \mathrm{~min}$ ), washed with ultrapure water and freeze-dried for further use.

\section{Incorporation of MSN/COOH/TAT-FITC with the YSA-BHQ1 peptides (MSN/COOH/TAT- FITC/Cit/YSA-BHQ1)}

Samples of MSN/COOH/TAT-FITC (10 mg) were dissolved in $10 \mathrm{~mL}$ sodium bicarbonate $(0.5 \mathrm{M}, \mathrm{pH} 9.0)$. Then $200 \mu \mathrm{L}$ Cit was slowly dropped into the solution under stirring (300 rpm) at room temperature overnight. During the reaction, aqueous $\mathrm{NaOH}$ was added to keep the $\mathrm{pH}$ of the reaction solution above 8 [45]. The samples were collected by centrifugation at $9000 \mathrm{rpm}$ for $5 \mathrm{~min}$, washed with ultrapure water and redispersed with $10 \mathrm{~mL}$ PBS buffer ( $\mathrm{pH}$ 7.4). Subsequently, $1 \mathrm{mg}$ YSA-BHQ1 peptide was added to the solution under stirring (300 $\mathrm{rpm}$ ) at room temperature. After $8 \mathrm{~h}$, the mixture was centrifuged at $9000 \mathrm{rpm}$ for $5 \mathrm{~min}$, washed with ultra-pure water to remove the redundant YSA-BHQ1 and freezedried for further use.

\section{Preparation of various DOX-loaded nano- particles}

DOX molecules were encapsulated by the diffusion method [46]. Briefly, $10 \mathrm{mg}$ samples of MSN/COOH, MSN/ COOH/TAT-FITC, or MSN/COOH/TAT-FITC/Cit/YSABHQ1 was dissolved in $10 \mathrm{~mL}$ PBS buffer $(\mathrm{pH}=7.4)$, then supplemented with $2 \mathrm{mg}$ DOX, respectively. After being stirred $(300 \mathrm{rpm})$ for $24 \mathrm{~h}$, the mixture was centrifuged (9000 rpm) for $5 \mathrm{~min}$, washed with PBS buffer to remove the excess DOX molecules, and freeze-dried for further use. The encapsulated DOX concentration was measured with a UV-Vis spectrophotometer (UV 722N, Shanghai Precision \& Scientific Instrument Co. Ltd, China) at a wavelength of $485 \mathrm{~nm}$. All processes were performed in the dark.

\section{Release behavior measurement of the DOX molecules}

The in vitro release behavior of the DOX molecules from MSN/COOH/TAT- FITC/Cit/YSA-BHQ1 was investigated in different PBS buffers $(\mathrm{pH}=7.4,6.0$, or $5.0)$ at $37^{\circ} \mathrm{C}$. Free DOX was used as a control. Samples of MSN/COOH/TAT-FITC/Cit/YSA-BHQ1/DOX (5 mg)

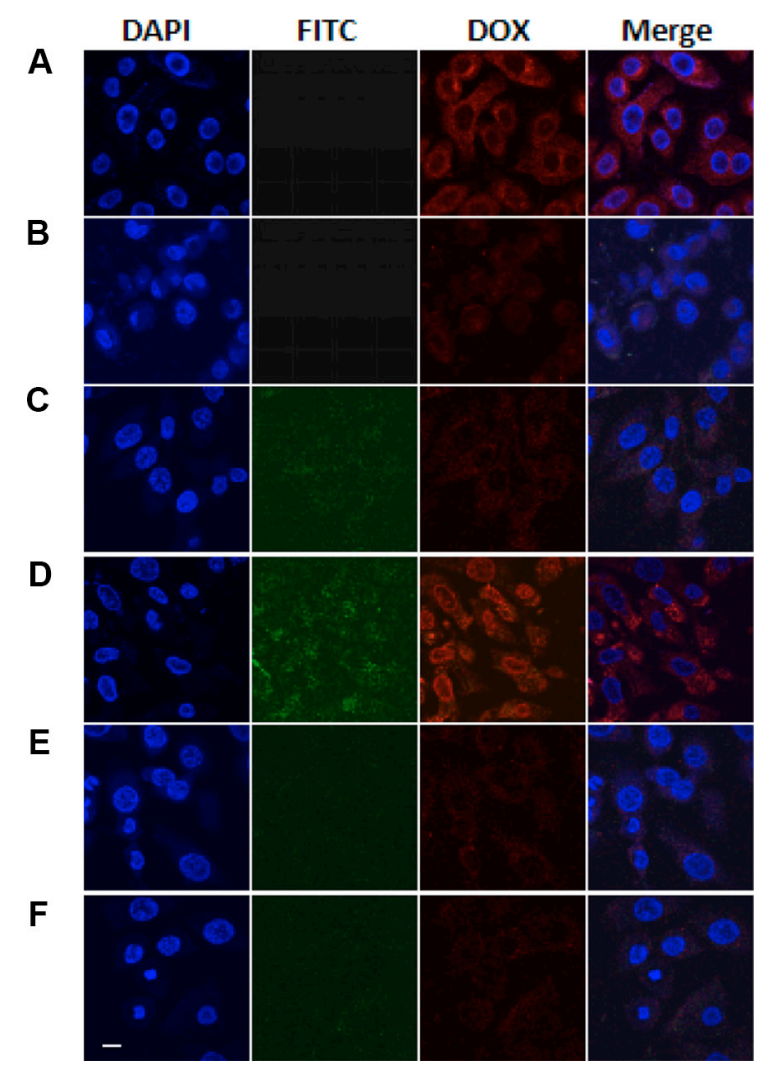

Figure 10: CLSM images of MCF-7 cells treated with free DOX (A), MSN/COOH/DOX (B), MSN/COOH/TAT-FITC/ DOX (C) or MSN/COOH/TAT-FITC/Cit/YSA- BHQ1/DOX (D). MCF-7 cells pretreated with YSA peptides and then treated with MSN/COOH/TAT-FITC/Cit/YSA-BHQ1/DOX (E) and HEK 293 cells treated with MSN/COOH/TAT-FITC/Cit/YSA- BHQ1/DOX (F) (DOX concentration of $5 \mu \mathrm{g} / \mathrm{mL}$ ) at $37^{\circ} \mathrm{C}$ for $2 \mathrm{~h}$. The red, green, and blue colors were regarded as the fluorescences of DOX, FITC, and DAPI, respectively. The scale bar is $10 \mu \mathrm{m}$. The brightness of FITC images have been enhanced by $20 \%$. 
were dispersed in $5 \mathrm{~mL}$ PBS buffer, and each sample was transferred into a dialysis bag (molecular weight cut-off $=7,000 \mathrm{Da}$ ). The bag was immerged into $200 \mathrm{~mL}$ of the corresponding PBS buffer at $37^{\circ} \mathrm{C}$ and shaken at 100 $\mathrm{rpm}$. At the desired time point, $3 \mathrm{~mL}$ of the PBS buffer outside the dialysis bag was removed for analysis. The concentration of DOX molecules in the PBS buffer was detected with a UV-Vis spectrophotometer at a wavelength of $485 \mathrm{~nm}$. The same volume of fresh PBS buffer was then added for further experiments.

\section{Cell culture}

MCF-7 and HEK293 cells were purchased from the Institute of Biochemistry and Cell Biology of the Chinese Academy of Sciences (IBCB, Shanghai, China). MCF7 cells were chosen for the experiments because they overexpress the EphA2 receptor, which can specifically bind to the YSA peptide. Cells were cultured in DMEM/highglucose medium containing $10 \% \mathrm{FBS}, 100 \mathrm{U} / \mathrm{mL}$ penicillin $\mathrm{G}$ sodium and $100 \mu \mathrm{g} / \mathrm{mL}$ streptomycin sulfate at $37^{\circ} \mathrm{C}$ and $5 \% \mathrm{CO}_{2}$ in a humidified incubator. The cell culture medium was renewed every $48 \mathrm{~h}$. For all experiments, cells were routinely harvested for measurement. The number of cells was calculated with a hemocytometer (Perlong Medical Instruments Inc., Nanjing, China).

\section{In vitro cytotoxicity}

The in vitro cytotoxicities of nano-particles or DOXloaded nanoparticles were assessed by the standard CCK8 test. MCF-7 and HEK293 cells were seeded in a 96well plate $\left(1 \times 10^{4}\right.$ cells/well $)$ for $24 \mathrm{~h}$ and then incubated with the blank (culture medium without nano-particles), free DOX or DOX-loaded nano-particles at different concentrations. After incubation for $24 \mathrm{~h}$, the culture medium was replaced with fresh medium containing 200 $\mu \mathrm{L}$ of $10 \% \mathrm{CCK}-8$ per well at $37^{\circ} \mathrm{C}$ for $2 \mathrm{~h}$. The number of viable cells was measured at a wavelength of $450 \mathrm{~nm}$ with an Automated Microplate Reader Infinite F50 (Tecan Group Ltd, Switzerland). The cytotoxicity was assessed by the percentage of viable cells relative to the blank control.

\section{Cell apoptosis}

The relative percentage of apoptotic cells was detected by flow cytometry. Briefly, MCF-7 and HEK293 cells were cultured in a six-well plate at an initial density of $2 \times 10^{4}$ cells $/ \mathrm{cm}^{2}$ and treated with free DOX, MSN/ COOH/DOX, MSN/COOH/TAT- FITC/Cit/YSA-BHQ1/ DOX, or MSN/COOH/TAT-FITC/Cit/YSA-BHQ1 nanoparticles (equivalent DOX concentration of $5 \mu \mathrm{g} / \mathrm{mL}$ ) for 24 $\mathrm{h}$, separately. The cells were then harvested, washed twice with ice-cold PBS buffer, stained with Annexin V-FITC and PI for 10 min in the dark, and analyzed on a FACSCalibur Flow Cytometer (Becton Dickinson Company, USA).

\section{Intracellular distribution of nano-particles}

The cellular uptake and intracellular distribution of nano-particles in the MCF-7 and HEK293 cells was observed with a Confocal Laser Scanning Microscope (CLSM) (Olympus, Japan). Briefly, the cells were seeded in a culture dish $\left(1 \times 10^{4}\right.$ cells/dish $)$ which was dedicated for the CLSM. After $24 \mathrm{~h}$, the culture medium was replaced with fresh medium containing free DOX, MSN/COOH/DOX, MSN/COOH/TAT-FITC or MSN/ $\mathrm{COOH} / \mathrm{TAT}-\mathrm{FITC} / \mathrm{Cit} / \mathrm{YSA}-\mathrm{BHQ1/DOX}$ (equivalent DOX concentration of $5 \mu \mathrm{g} / \mathrm{mL}$ ) followed by incubation for another $2 \mathrm{~h}$. Then, the culture medium was discarded, and the cells were washed three times with PBS buffer to remove the extracellular free DOX molecules or nano-particles. DAPI was then used to stain the nuclei, according to the manufacturer's instructions. Next, the cells were washed three times with PBS buffer to remove the extracellular DAPI and were observed with the CLSM. As a further determination of the involvement of the EphA2 receptors in the cellular uptake of the nanoparticles, the MCF-7 cells were preprocessed with excess YSA peptides for $1 \mathrm{~h}$. The cells were then washed with PBS buffer to remove the extracellular free YSA peptides, treated with MSN/COOH/TAT-FITC/Cit/YSA- BHQ1/ DOX for $2 \mathrm{~h}$, washed with the PBS buffer, stained with DAPI, and observed with the CLSM.

\section{The fluorescent pH sensitivity of MSN/COOH/ TAT-FITC/Cit/YSA-BHQ1}

The fluorescence of MSN/COOH/TAT-FITC/ Cit/YSA-BHQ1 under different $\mathrm{pH}$ conditions was observed with a fluorescence microscope (Shanghai Bimu Instrument Co. Ltd, China). Briefly, $1 \mathrm{mg} \mathrm{MSN} / \mathrm{COOH} /$ TAT-FITC/Cit/YSA-BHQ1 was dissolved in $5 \mathrm{~mL}$ PBS buffer ( $\mathrm{pH}$ 7.4). Then the solution was equally divided into four tubes and the pHs were adjusted to 5.5, 6.5, 7.4, and 8.0, separately. For comparison, $0.2 \mathrm{mg} \mathrm{MSN} / \mathrm{COOH} /$ TAT-FITC or MSN/COOH/TAT-FITC/Cit was dissolved in $1 \mathrm{~mL}$ PBS buffer ( $\mathrm{pH}$ 7.4). Then, the fluorescence of each solution was observed with the fluorescence microscope. The fluorescence intensities of the solutions were measured with a Fluostar Optima fluorescence microplate reader (BMG Labtech GmbH, Ortenberg, Germany) at excitation and emission wavelengths of $490 \mathrm{~nm}$ and $530 \mathrm{~nm}$, respectively.

\section{Characterization of the nano-particles}

The shapes and sizes of the nano-particles were observed with a transmission electron microscope (TEM) (JEOL JEM-1200EX microscope, Japan). The infrared spectra were inspected with a Fourier transform infrared (FT-IR) spectrometer (Nicolet Co., USA). The zeta potentials of the nano-particles were measured with a 
Malvern zetasizer 3000 (England). Nitrogen adsorptiondesorption isotherms were acquired with a Quantachrome Nova 3000 Brunauer-Emmett-Teller specific surface area analyzer (Quantachrome Instruments, USA) at $-196^{\circ} \mathrm{C}$. Prior to the adsorption experiment, the samples were outgassed under a vacuum at $40^{\circ} \mathrm{C}$ for $6 \mathrm{~h}$. The surface areas of the nano-particles were calculated by the BrunauerEmmett-Teller means. The pore size distribution was determined from the nitrogen adsorption isotherms through the Barrett-Joynere-Halenda method. Thermogravimetric analysis was performed with a thermogravimetry analyzer (Pyris 1, PerkinElmer Co., USA) at a heating rate of $10^{\circ} \mathrm{C}$ $\mathrm{min}^{-1}$ in a $\mathrm{N}_{2}$ atmosphere from $30^{\circ} \mathrm{C}$ to $800^{\circ} \mathrm{C}$.

\section{Statistical analysis}

All experiments were carried out in triplicate and the obtained data were expressed as the mean \pm standard deviation (SD). Student's $t$-test was used for statistical analysis. $P<0.05$ was considered statistically significant.

\section{CONCLUSIONS}

As illustrated in Scheme 1, the carboxyl groups were first modified on the surface of the MSN. Then, TAT peptides labeled with fluorescein isothiocyanate (FITC) were linked to the carboxyl groups. At this time, citraconic anhydride (Cit), an $\alpha$-methyl derivative of maleic anhydride, was mixed with MSN/COOH/TATFITC in order to convert the primary amino groups of the TAT peptides into carboxyl groups by forming citraconic amides [47-49] (Figure 11). This was the first inversion of the TAT peptide charge (positive charge $\rightarrow$ negative charge). The resulting negatively charged TAT peptides could electrostatically bind with the positively charged YSA-BHQ1 peptides. The latter are short peptides that specifically bind to the EphA2 receptor, which is overexpressed in several cancer cell lines [33-35]. Finally, doxorubicin hydrochloride (DOX) molecules were trapped into the MSN. Due to the combination of the TAT and YSA peptides, the nuclear targeting activity of the TAT peptides was temporarily shielded. At the same time, the quenching group (BHQ1), which was used to tag the YSA peptides, closely approached FITC and quenched its fluorescence via fluorescence resonance energy transfer.
Citraconic amide is relatively stable in neutral and weak alkaline conditions, but is hydrolyzed readily in acidic media because the neighboring carboxylic acid group facilitates intramolecular catalysis, which regenerates its primary amine functionality [47, 48, 50-52] (Figure 11). Therefore, the positive charge of the TAT peptide was restored in this second charge reversal (negative charge $\rightarrow$ positive charge). Due to charge repulsion, the YSA peptides on the nano-particles separated from the TAT peptides. Thus, the TAT peptides (which were previously shielded by the YSA peptides) were exposed again, the nuclear targeting potential was restored, and FITC reemitted fluorescence. The TAT peptide then could combine with the nuclear pore complex on the karyotheca to form the transport complex, nanoparticle/importin $\alpha / \beta$. Subsequently, the drug carrier nano-particles were transferred into the nucleus. Lastly, the DOX molecules were released from the nano-particles, acted on the DNA double-strand, and caused the apoptosis of the tumor cells.

This nano-drug delivery vehicle had four notable features: 1. Active and passive targeting of tumor cells. The outermost YSA peptides could specifically bind to the EphA2 receptors, therefore facilitating the cellular uptake of the nano-particles. Meanwhile, due to the enhanced permeability and retention effect, the nano-drug-delivery vehicle could easily accumulate in the tumor cells. 2 . $\mathrm{pH}$ sensitive fluorescent probe. Because citraconic amide is stable in neutral and weak alkaline environments, the fluorescence of FITC was quenched by BHQ1. Thus, the fluorescence should be minimal in the blood circulation and normal tissues. On the other hand, in acidic conditions (like those of tumor tissues/cells), the citraconic amide was quickly hydrolyzed and the YSA peptides were repelled from the nano-particles, so FITC emitted fluorescence again; thus, the signal-to-noise ratio was maximized. 3. High-efficiency intranuclear drug delivery. The temporary masking of the positive charges of the TAT peptides should reduce their clearance from the circulation. Through this "Trojan Horse" method [9], the nano-particles should be safely escorted into tumor cells. 4. Simultaneous diagnostics and therapeutics. Fluorescence imaging can be used not only to assess tumor development, but also to determine the therapeutic performance of the drugdelivery system. Therefore, MSN/COOH/TAT-FITC/

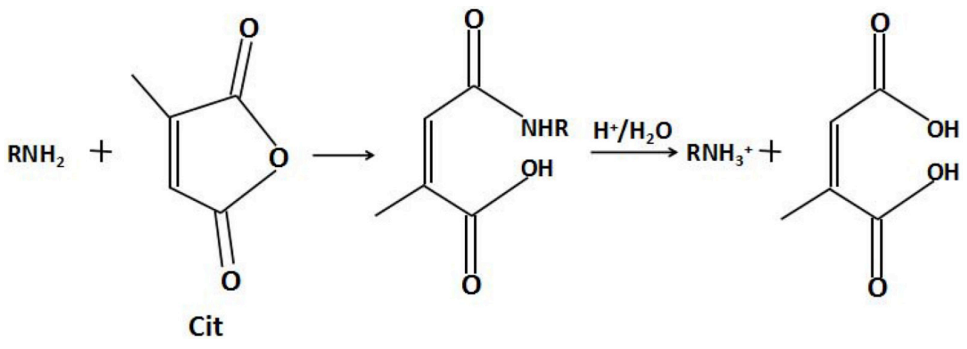

Figure 11: Schematic illustration of the charge inversion of a peptide amino. 
Cit/YSA-BHQ1/DOX could be a promising nano-drug delivery system for cancer imaging and therapy.

\section{ACKNOWLEDGMENTS AND FUNDING}

This work was supported by the National Natural Science Foundation of China (No. 81603016, 30970809, 81271636), the Natural Science Foundation of Jiangsu Province (No. BK20160706), and the advantage discipline construction fund (No.1124007002) and the Fundamental Research Funds from Southeast University (No.3224006418).

\section{CONFLICTS OF INTEREST}

The authors declared no conflicts of interest.

\section{REFERENCES}

1. Jemal A, Bray F, Center MM, Ferlay J, Ward E, Forman D. Global cancer statistics. CA Cancer J Clin. 2011; 61:69-90.

2. Lopez-Tarruella S, Martin M. Recent advances in systemic therapy: advances in adjuvant systemic chemotherapy of early breast cancer. Breast Cancer Res. 2009; 11:204-219.

3. Ferrari M. Cancer nanotechnology: opportunities and challenges. Nat Rev Cancer. 2005; 5:161-171.

4. Ji X, Peng F, Zhong Y, Su Y, Jiang X, Song C, Yang L, Chu B, Lee ST, He Y. Silicon drug nanocarriers: highly fluorescent, photostable, and ultrasmall silicon drug nanocarriers for long-term tumor cell tracking and invivo cancer therapy. Adv Mater. 2015; 27:1131.

5. Ren X, Chen H, Yang VC, Sun D. Iron oxide nanoparticlebased theranostics for cancer imaging and therapy. Front Chem Sci Eng. 2014; 8:253-264.

6. Du C, Deng D, Shan L, Wan S, Cao J, Tian J, Achilefu S, $\mathrm{Gu}$ Y. A pH-sensitive doxorubicin prodrug based on folate-conjugated BSA for tumor-targeted drug delivery. Biomaterials. 2013; 34:3087-3097.

7. Deng K, Hou Z, Li X, Li C, Zhang Y, Deng X, Cheng Z, Lin J. Aptamer-mediated up-conversion core/mof shell nanocomposites for targeted drug delivery and cell imaging. Sci Rep. 2015; 5:7851-7858.

8. Shin MC, Zhang J, Min KA, Lee K, Byun Y, David AE, He H, Yang VC. Cell-penetrating peptides: achievements and challenges in application for cancer treatment. J Biomed Mater Res. 2014; 102:575-587.

9. Huang Y, Jiang Y, Wang H, Wang J, Shin MC, Byun Y, He H, Liang Y, Yang VC. Curb challenges of the "Trojan Horse" approach: smart strategies in achieving effective yet safe cell-penetrating peptide-based drug delivery. Adv Drug Deliv Rev. 2013; 65:1299-1315.

10. Wang G, Reed E, Li QQ. Molecular basis of cellular response to cisplatin chemotherapy in non-small cell lung cancer (Review). Oncol Rep. 2004; 12:955-965.
11. Mo R, Sun Q, Xue J, Li N, Li W, Zhang C, Ping Q. Multistage $\mathrm{pH}$-responsive liposomes for mitochondrialtargeted anticancer drug delivery. Adv Mater. 2012; 24:3659-3665.

12. Drappier C, Oliveira H, Sandre O, Ibarboure E, Combet S, Garanger E, Lecommandoux S. Self-assembled core-shell micelles from peptide-b-polymer molecular chimeras towards structure-activity relationships. Faraday Discuss. 2013; 166:83-100.

13. Kalderon D, Richardson WD, Markham AF, Smith AE. Sequence requirements for nuclear location of simian virus 40 large-T antigen. Nature (London). 1984; 311:33-38.

14. Nakielny S, Dreyfuss G. Transport of proteins and RNAs in and out of the nucleus. Cell. 1999; 99:677-690.

15. Patel SS, Belmont BJ, Sante JM, Rexach MF. Natively unfolded nucleoporins gate protein diffusion across the nuclear pore complex. Cell. 2007; 129:83-96.

16. Alber F, Dokudovskaya S, Veenhoff LM, Zhang W, Kipper J, Devos D, Suprapto A, Karni-Schmidt O, Williams R, Chait BT, Sali A, Rout MP. The molecular architecture of the nuclear pore complex. Nature. 2007; 450:695-701.

17. Ruben S, Perkins A, Purcell R, Joung K, Sia R, Burghoff R, Haseltine WA, Rosen CA, Virol J. Structural and functional characterization of human immuno- deficiency virus TAT protein. J Virol. 1989; 63:1-8.

18. Loret EP, Vives E, Ho PS, Rochat H, Vanrietschoten J, Johnson WC. Activating region of HIV-1 TAT proteinvacuum UV circular-dichroism and energy minimization. Biochemistry. 1991; 30:6013-6023.

19. Fawell S, Seery J, Daikh Y, Moore C, Chen LL, Pepinsky B, Barsoum J. TAT-mediated delivery of heterologous proteins into cells. Proc Natl Acad Sci USA. 1994; 91:64-68.

20. Jin E, Zhang B, Sun X, Zhou Z, Ma X, Sun Q, Tang J, Shen Y, Van Kirk E, Murdoch WJ, Radosz M. Acid-active cell-penetrating peptides for in vivo tumor-targeted drug delivery. J Am Chem Soc. 2013; 135:933-940.

21. Ambrogio MW, Thomas CR, Zhao YL, Zink JI, Stoddart JF. Mechanized silica nanoparticles: a new frontier in theranostic nanomedicine. Acc Chem Res. 2011; 44:903-913.

22. Luo Z, Cai K, Hu Y, Zhao L, Liu P, Duan L, Yang WH. Mesoporous silica nanoparticles end-capped with collagen: redox-responsive nanoreserviors for targeted drug delivery. Angew Chem Int Ed. 2011; 50:640-643.

23. Ashley CE, Carnes EC, Phillips GK, Padilla D, Durfee PN, Brown PA, Hanna TN, Liu JW, Plillips B, Carter MB, Carroll NJ, Jiang XM, Dunphy DR, et al. The targeted delivery of multicomponent cargos to cancer cells by nanoporous particle-surpported lipid bilayers. Nat Mater. 2011; 10:389-397.

24. Tang F, Li L, Chen D. Mesoporous silica nanoparticles: synthesis, bio- compatibility and drug delivery. Adv Mater. 2012; 24:1504-1534. 
25. Tarn D, Ashley CE, Xue M, Carnes EC, Zink JI, Brinker CJ. Mesoporous silica nanoparticle nanocarriers: biofunctionality and biocompatibility. Acc Chem Res. 2013; 46:792-801.

26. Chen Y, Chen H, Shi J. In vivo biosafety evaluations and diagnostic/therapeutic applications of chemically designed mesoporous silica nanoparticles. Adv Mater. 2013; 25:3144-3176.

27. Piao Y, Burns A, Kim J, Wiesner U, Hyeon T. Designed fabrication of silica-based nanostructured particle system for nanomedicine applications. Adv Funct Mater. 2008; 18:3745-3758.

28. Pan L, He Q, Liu J, Chen Y, Ma M, Zhang L, Shi J. Nuclear-targeted drug delivery of TAT peptide-conjugated monodisperse mesoporous silica nanoparticles. J Am Chem. Soc, 2012; 134:5722-5725.

29. Otten R, Mulder FAA, Kralt A, Hapsari RA, Meinema AC, Veenhoff LM, Laba JK, Poolman B, van den Bogaart G, Lusk CP. Long unfolded linkers facilitate membrane protein import through the nuclear pore complex. Science. 2011; 333:90-93.

30. Silverstein RM, Webster FX. Spectrometric Identification of Organic Compounds, 6th ed., Wiley, New York:1998.

31. Solomons T W G, Fryhle C. Organic Chemistry, 7th ed., Upgrade, Wiley, New York: 2001.

32. Dugas V, Chevalier Y. Surface hydroxylation and silane grafting on fumed and thermal silica. J Colloid Interface Sci. 2003; 264:354-361.

33. Koolpe M, Dail M, Pasquale EB. An ephrin mimetic peptide that selectively targets the EphA2 receptor. J Biol Chem. 2002; 277:46974-46979.

34. Pasquale EB. Eph receptors and ephrins in cancer: bidirectional signalling and beyond. Nat. Rev. Cancer. 2010; 10:165-180.

35. Wykosky J, Debinski W. The EphA2 receptor and ephrin A1 ligand in solid tumors: function and therapeutic targeting. Mol. Cancer Res. 2008; 6:1795-1806.

36. Sayantan Mitra, Srinivas Duggineni, Mitchell Koolpe, Xuejun Zhu, Ziwei Huang, and Elena B. Pasquale. Structure-activity relationship analysis of peptides targeting the EphA2 receptor. Biochemistry. 2010; 49:6687-6695.

37. Wang S, Placzek WJ, John L. Stebbins, Sayantan Mitra, Roberta Noberini, Mitchell Koolpe, Ziming Zhang, Russell Dahl, Elena B. Pasquale, Maurizio Pellecchia. Novel targeted system to deliver chemotherapeutic drugs to EphA2-expressing cancer cells. J Med Chem. 2012; 55: 2427-2436.

38. Alaaldin M. Alkilany, Stefano P. Boulos, Samuel E. Lohse, Lucas B. Thompson, and Catherine J. Murphy. Homing Peptide-Conjugated Gold Nanorods: The effect of amino acid sequence display on nanorod uptake and cellular proliferation. Bioconjugate Chem. 2014; 25:1162-1171.

39. He X, Nie H, Wang K, Tan W, Wu X, Zhang P. In vivo study of biodistribution and urinary excretion of surface-modified silica nanoparticles. Anal Chem. 2008; 80:9597-9603.
40. Kobler J, Moller K, Bein T. Colloidal suspensions of functionalized mesoporous silica nanoparticles. ACS Nano. 2008; 2:791-799.

41. Zhang GL, Gao J, Qian JC, Zhang L, Zheng K, Zhong K. Hydroxylated mesoporous nanosilica coated by polyethylenimine coupled with Gadolinium and folic acid: a tumor-targeted T1 magnetic resonance contrast agent and drug delivery system. ACS Appl. Mater. Interfaces. 2015; 7:14192-14200.

42. Yang K, Luo H, Zeng M, Jiang Y, Li J, Fu X. Intracellular $\mathrm{pH}$-triggered, targeted drug delivery to cancer cells by multifunctional envelope-type mesoporous silica nanocontainers. ACS Appl. Mater. Interfaces. 2015; 7:17399-17407.

43. Liu XH, Zhang JT, Lynn DM. Polyelectrolyte multilayers fabricated from 'charge-shifting' anionic polymers: a new approach to controlled film disruption and the release of cationic agents from surfaces. Soft Matter. 2008; 4:1688-1695.

44. luo Z, Cai K, Hu Y, Zhang B, Xu D. Cell-specific intracellular anticancer drug delivery from mesoporous silica nanoparticles with $\mathrm{pH}$ sensitivity. Adv Healthcare Mater. 2012; 1:321-325.

45. Tewey K, Rowe T, Yang L, Halligan B, Liu L. Adriamycininduced DNA damage mediated by mammalian DNA topoisomerase. Science. 1984; 226:466-468.

46. Luo Z, Ding X, Hu Y, Wu S, Xiang Y, Zeng Y, Zhang B, Yan H, Zhang H, Zhu L, Liu J, Li J, Cai K, et al. Engineering a hollow nanocontainer platform with multifunctional molecular machines for tumor-targeted therapy in vitro and in vivo. ACS Nano. 2013; 7:10271-10284.

47. Kirby AJ, Lancaster PW. Structure and efficiency in intramolecular and enzymic catalysis. Catalysis of amide hydrolysis by the carboxy-group of substituted maleamic acids. JCS Perkin. 1972; 1206-1214.

48. Aldersle MF, Kirby AJ, Lancaster PW, Mcdonald RS, Smith CR. Intramolecular catalysis of amide hydrolysis by the carboxy-group. Rate determining proton transfer from external general acids in the hydrolysis of substituted maleamic acids. JCS Perkin. 1974; 1487-1495.

49. Rozema DB, Ekena K, Lewis DL, Loomis AG, Wolff JA. Endosomolysis by masking of a membrane-active agent (EMMA) for cytoplasmic release of macromolecules. Bioconjugate Chem. 2003; 14:51-57.

50. Lee Y, Fukushima S, Bae Y, Hiki S, Ishii T, Kataoka K. A protein nanocarrier from charge-conversion polymer in response to endosomal pH. J Am Chem Soc. 2007; 129:5362-5365.

51. Meyer M, Zintchenko A, Ogris M, Wagner E. A dimethytmateic acid-metittin- potytysine conjugate with reduced toxicity, $\mathrm{pH}$ triggered endosomolytic activity and enhanced gene transfer potential. J Gene Med. 2007; 9:797-805.

52. Shen Y, Zhou Z, Sui M, Tang J, Xu P, Van Kirk EA, Murdoch WJ, Fan M, Radosz M. Charge-reversal polyamidoamine dendrimer for cascade nuclear drug delivery. Nanomedicine (Lond). 2010; 5:1205-1217. 